\section{CHRONIC OBSTRUCTIVE PULMONARY DISEASE AND DEPRESSION}

\section{Ivana Jelić}

Faculty of Medical Sciences, University of Kragujevac, Kragujevac, Serbia

\section{INTRODUCTION}

Chronic obstructive pulmonary disease (COPD) is the most common respiratory disease in the population of working age people and represents a very serious health problem in both developed and developing world.

The data on the prevalence of chronic obstructive pulmonary disease are very different, because the disease is often not recognized and not diagnosed, even in

\section{Summary}

The prognosis of patients with chronic obstructive pulmonary disease is still uncertain, especially when the primary disease is further complicated with depression symptoms, the treatment of which represents a very complex therapeutic problem. Depression symptoms appear very often in patients suffering from chronic obstructive pulmonary disease, and the prevalence identified in different studies is from $16 \%$ to $74 \%$. The variability in the study is caused by the different stages of the disease in which patients are found at the time of observation, assessment methods and the different diagnostic criteria for chronic obstructive pulmonary disease and depression. Chronic obstructive pulmonary disease is associated with numerous comorbidities, (including depression) and it is significant since it leads to more frequent use of health services, frequent hospitalizations and poor physical and social functioning. Patients suffering from chronic obstructive lung diseases are among the most accessible populations suitable for preventive work: they are the high-risk population and in constant contact with health professionals that can facilitate diagnosis and timely treatment of depression symptoms.

Key words: chronic obstructive pulmonary disease, prevalence, depression

the range from $56 \%$ to $85 \%$ of the cases [1-2]. The substantial consumption of nicotine represents one of the major factors for chronic obstructive pulmonary disease [3]. The meta-analysis has shown that excessive consumption of nicotine, associated with a genetic predisposition, represents the major factor in causing lung damage. According to the metaanalysis being conducted in 28 countries during the period from 1990 to 2004, the prevalence of chronic obstructive pulmo- 
nary disease was said to be $7.6 \%$; COPD was reported to be higher in smokers and ex-smokers compared to non-smokers and noted to be prevalent in population over 40 years of age being present more in men than in women [4]. The BOLD study conducted in 12 world countries, both developed and developing ones, with 9425 respondents estimated $10.1 \%$ of prevalence of chronic obstructive pulmonary disease. In a study conducted in South America, the prevalence of chronic obstructive pulmonary disease was determined from $7.8 \%$ to $20 \%$ of cases [56].

According to the definition of the Global Strategy for the Diagnosis, treatment and prevalence of chronic obstructive pulmonary disease (GOLD) is characterized by airflow limitation which is not fully reversible, progressive and associated with an abnormal inflammatory lung response to harmful particles and gases. The airflow limitation is based on the inflammation occurring in the small airways and lung parenchyma. Chronic $\rightarrow \quad$ inflammation causes structural changes $\ddot{\Delta} \quad$ and narrowing of the small airways. The destruction of the parenchyma, occurring as a part of the inflammatory process, leads to the reduction of elasticity being followed by the destruction of the lung parenchyma and the development of emphysema $[1,2,8]$.

The clinical diagnosis of chronic obstructive pulmonary disease is based on characteristic symptoms such as the existence of dyspnea, chronic cough and sputum production, and history and spirometric examinations. Forced expiratory lung capacity (FEV1) is the most commonly used parameter in assessing the lung function damage. The ratio of FEV1 / FVC $<70 \%$ indicates obstructi- ve lung ventilation, while the assessment of the severity of obstructive disorders is based on the FEV 1 value [1].

The assessment of severity of chronic obstructive pulmonary disease is performed on the basis of FEV1. In relation to the value of FEV1, there are mild, moderately severe, severe and very severe chronic obstructive pulmonary diseases. The value of FEV1 $<80 \%$ characterizes mild chronic obstructive pulmonary disease, $50-80 \%$ moderately severe, $30-50 \%$ severe and $<30 \%$ very severe chronic obstructive pulmonary disease.

Chronic obstructive pulmonary disease is often accompanied by depression symptoms. It is difficult to differentiate between depression and chronic obstructive pulmonary disease because their symptoms are intertwined. A large number of psychological and physical symptoms refer to both disorders: increased symptoms of fatigue, sleep disturbance, appetite, concentration difficulty, reduced mobility and deceleration [7-8]. People with depression, smoke more frequently and more intensely, so it reflects negatively on the smoking cessation. Depression in patients with chronic obstructive pulmonary disease reduces the quality of life and reduces work capacity [9]. A regular monitoring of the quality of li$\mathrm{fe}$ is an important parameter in the clinical management of patients, because indicators such as lung function are of limited value. The research results show that the respiratory and physical symptoms are associated with depression in patients with chronic obstructive pulmonary disease while that is not the case with the factors such as age, sex, education, FEV1 and comorbidities [10]. FEV1 is accepted as a reliable indicator of physiological severity of chronic obstructive pulmonary 
disease, according to many studies, but it correlates poorly with measurements of life quality and the results reported by the depressed patients [10-12]. The stable chronic obstructive pulmonary disease prevalence of depression ranges between $10-42 \%$ [12-17]. The risk of depression is higher in patients with a more severe clinical picture of chronic obstructive pulmonary disease compared to the healthy population $(15 \%)$, with the highest percentage $(62 \%)$ found in patients with long-term oxygen therapy (DOT) [17]. In some studies, it is estimated that depression in chronic obstructive pulmonary disease occurs in the range from $6 \%$ to 59 $\%$ [20]. The systematic analysis of 64 studies involving patients with severe clinical picture of chronic obstructive pulmonary disease showed that the prevalence of depression varied between 37-71 $\%$ in chronic obstructive pulmonary disease and was even higher than the prevalence of depression in patients with cancer, AIDS, heart disease and kidney disease [14-22]. In our research, conducted in primary health care in 2014 , as an instrument of assessment of depression a screening questionnaire was used, created by the experts of the Ministry of Health of the Republic of Serbia. 835 patients were analyzed and fortified the prevalence of depressive symptoms higher than $9 \%$ in patients with more severe clinical picture of chronic obstructive pulmonary disease.

The mechanism of the development of depression in chronic obstructive pulmonary disease is multifactorial [17]. Nowadays there are more and more studies proving that systemic inflammation leads to the appearance of depression symptoms. Interleukin-6 (IL-6) plays a particularly important role because it is increased in sputum, exhaled air and plasma of patients with chronic obstructive pulmonary disease, particularly during exacerbations. The concentration of IL-6 in plasma is correlated with increased Creactive protein (CRP) levels, being a major stimulator of CRP release from the liver. Since IL-6 is stable in the circulation, in contrast to other cytokines, it is considered to be involved in some of the systemic effects of chronic obstructive pulmonary disease. IL-6 is claimed to particularly contribute to the damage in endothelial cells functions, insulin resistance, osteoporosis and depression in patients with chronic obstructive pulmonary disease [19].

The symptoms of chronic obstructive pulmonary diseases such as dyspnea, inactivity and consequential condition loss are claimed to cause even greater inactivity, social isolation, anxiety and symptoms of depression. Such patients often feel useless, are dependent on others in terms of care and worry and lose interest in future events [23].

Several studies on development of depression in chronic obstructive pulmonary disease patients were conducted. The study by Polski and associates in 2005 that lasted ten years was one of the largest studies. 8387 adult patients were included and the emergence of depression symptoms after the diagnosis of one of the seven most common chronic diseases, including chronic obstructive pulmonary disease, was investigated. The control check-ups were performed every two years. Two years after the diagnosis of chronic obstructive pulmonary disease it was observed that the "hazard ratio" for the development of depression was 2.21, 3.55 for cancer and 1.45 for heart disease [25]. Patients with chronic ob- 
structive pulmonary disease have a variety of symptoms, ranging from shortterm depression symptoms and clinically manifested depression. Several studies claimed that two thirds of patients with chronic obstructive pulmonary disease had a moderate to severe depression [2730]. The study by Johannes and associates in 2003 reported that about one-quarter of patients with chronic obstructive pulmonary disease had an unrecognized depression.

\section{Assessment of depression in chronic obstructive pulmonary disease}

No diagnostic screening tool for the assessment of depression in patients with chronic obstructive pulmonary disease has been developed, so far, so the most commonly used instruments for depression symptoms assessment are the Beck Depression Inventory (BDI Beck Depression inventors) and Hamilton Depression (HRSD-Hamilton depression scale) [31].

According to the GOLD guidelines, a detailed medical history of each newly detected patient with chronic obstructive pulmonary disease is recommended to be taken, including the assessment of depression symptoms [32-33].

The recommendations from the United States (United States Preventive Task
Force) state that all patients over 18 years of age should be screened for the presence of depression symptoms in primary care offices. All chronic patients and patients with chronic obstructive pulmonary disease should be included [33].

\section{CONCLUSION}

Treatment of depression in patients with chronic obstructive pulmonary disease is multidisciplinary. The available medical treatment focuses on depression allievation symptoms, maintaining the basic functioning and improving the quality of life which would enable clinicians to recognize the disease deteriorations.

Patients suffering from chronic obstructive lung diseases are among the most accessible populations suitable for preventive work: they are a high-risk population and in constant contact with health professionals that can facilitate diagnosis and timely treatment of depression symptoms.

Bearing in mind the predictions of the World Health Organization, that by 2020 depression will have become the leading cause of mortality in the world and since it is now one of the medical conditions greatly affecting the deterioration of quality of life, adequate prevention is an imperative. 


\section{HRONIČNA OPSTRUKTIVNA BOLEST PLUĆA I DEPRESIJA}

\section{Ivana Jelić}

Fakultet medicinskih nauka, Univerzitet u Kragujevcu, Kragujevac, Srbija

\section{References:}

1. Barns PJ. Chronic Obstructive pulmonary Disease: Effect beyond the lungs. Plos Med

2. 2010;7(3):e1000220.doi10.1371/journal.pmed.1000220.

3. Global Strategy for the Diagnosis, Management and Prevention of COPD, Global

4. Initative for Chronic Obstructive Lung Disease (GOLD) 2013. Available from:

5. http://www.goldcopd.org/.

6. Stang P, Lydick E, Silberman $\mathrm{C}$ et al. The Prelevance of COPD; Using Smoking Rates to Estimate Disease Frequency in the General Population. Chest 2000;117:354-359.

7. Halbert RJ, Natoli JL, Gano A, et al. Global burden of COPD: systematic review and meta-analysis. Eur Respir J 2006;25:523-32

\section{Sažetak}

Prognoza bolesnika sa hroničnom opstruktivnom bolešću pluća je i dalje neizvesna, pogotovo kada je osnovno oboljenje komplikovano simptomima depresije čije lečenje prestavlja vrlo složen terapijski problem. Simptomi depresije javljaju se veoma često kod pacijenata koji boluju od hronične opstruktivne bolesti pluća, a utvrđena prevalenca u različitim studijama kreće se od $16 \%$ do $74 \%$. Varijabilnost u studijama potiče od faze bolesti u kojoj se pacijenti nalazili u trenutku opservacije, metodama procene kao i različitim dijagnostičkim kriterijumima za hroničnu opstruktivnu bolest pluća i depresiju. Hronična opstruktivna bolest pluća udružena sa brojnim komorbiditetima, među kojima je i depresija, zauzima značajno mesto jer dovodi do češceg korišćenja zdravstvenih usluga, češćih hospitalizacija, lošim fizičim i socijalnim funkcionisanjem. Bolesnici koji pate od hronične opstruktivne bolesti pluća spadaju u veoma dostupnu populaciju pogodnu za preventivni rad, pre svega zato što su visoko rizična populacija, a zatim i zbog toga što su u stalnom kontaktu sa zdravstvenim radnicima što olakšava dijagnostikovanje i blagovremeno lečenje simptoma depresije.

Ključne reči: hronična opstruktivna bolest pluća, prevalenca, depresija

8. Raherison C, Girodet PO. Epidemiology of COPD. Review. Eur Respir Rev 2009;

9. 18:114,213-221

10. Menezes AM, Perez-Padilla R, Jardim JR, et al. Chronic obstructive pulmonary disease in five Latin American cities (the PLATINO study): a prelevance study. Lancet 2005;366:1875-1881

11. Buist AS, McBurnie MA, Vollmer WM, et al. International variation in the prelevance of COPD (the BOLD Study): a population-based prelevance study. Lancet. 2007;370:741-50.

12. Barnes PJ. Chronic obstructive pulmonary disease. N Engl J Med 2000;343:269-80.

13. Wilson lan. Depression in the patient with COPD. International Journal of COPD 
14. 2006:1(1)61-64.

15. Rabe KF, Hurd S, Anzueto A, et al. Global strategy for the diagnosis, management, and prevention of chronic obstructive pulmonary disease: GOLD executive summary. Am J Respir Crit Care Med. 2007;176:532555.

16. United States Preventive Task Force http://www.uspreventiveservicestaskforce.org/about.htm.

17. Maurer J, Rebbapragada V, Borson S, et al. Anxiety and Depression in COPD. Chest 2008; 134:43-56.

18. Kunik ME, Roundy K, Veazey C, et al. Surprisingly high prevalence of anxiety and depression in chronic breathing disorders. Chest 2005;127:1205-1211.

19. Van Manen JG, Bindels PJ, Dekker FW, et al. Risk of depression in patients with chronic obstructive pulmonary disease and its determinants. Thorax 2002;57:412-416.

20. Wagena EJ, Kant I, van Amelsvoort LG, et al. Risk of depression and anxiety in employees with chronic bronchitis: the modifying effect of cigarette smoking.

21. Psychosom Med. 2004;66:729-734.

22. Lacasse Y, Rousseau L, Maltais F. Prelevance of depressive symptoms and depression in patients with severe oxygen dependent chronic obstructive pulmonary disease. J Cardiopulm Rehabil. 2001;21:80-86.

23. Gudmundsson G, Gislason T, Janson C, et al. Depression, anxiety and health status after hospitalization for COPD: a multicentre study in the Nordic countries. Respir Med. 2006;100:87-93.

24. Van den Bemt L, Schermer T, Bor H, et al. The risk for depression comorbidity in patients eith COPD. Chest 2009;135:108-114.

25. Solano JP, Gomes B, Higginson IJ. A comparison of symptom prevalence in far advanced cancer, AIDS, heart disease, chronic obstructive pulmonary disease and renal disease. J Pain Symptom Manage. 2006;31:58-69.

26. Barns PJ. The Cytokine Network in Chronic Obstructive Pulmonary Disease. Am J Respir Cell Mol Biol 2009;41:631-638.

27. Yohannes AM, Baldwin RC, Connolly MJ. Depression and anxiety in elderly patients with chronic obstructive pulmonary disease. Age Ageing 2006;35:457-459.

28. Polsky D, Doshi JA, Marcus S, et al. Longterm risk for depressive symptoms after a medical diagnosis. Arch Intern Med 2005;165:1260-1266.
29. Yohannes AM, Baldwin RC, Connolly MJ. Depression and anxiety in elderly outpatients with chronic obstructive pulmonary disease: prevalence, and validation of the Basdec screening questionnaire. Int J Geriatr Psychiatry. 2000;15:1090-1096.

30. Kim HF, Kunik ME, Molinari VA, et al. Functional impairment in COPD patients: the impact of anxiety and depression. Psychosomatics. 2000;41:465-471.

31. Yohannes AM, Baldwin RC, Connolly MJ. Prevalence of sub-threshold depression in elderly patients with chronic obstructive pulmonary disease. Int J Geriatr Psychiatry.

32. 2003;18:412-416.

33. Ciechanowski PS, Katon WJ, Russo JE. Depression and diabetes: impact of depressive symptoms on adherence, function, and costs. Arch Intern Med. 2000;160:32783285.

34. Sullivan M, Simon G, Spertus J, et al. Depression-related costs in heart failure care. Arch Intern Med. 2002;162:1860-1866.

35. Lustman PJ, Anderson RJ, Freedland KE, et al. Depression and poor glycemic control: a meta-analytic review of the literature. Diabetes Care 2000;23:934-942.

36. Timotijević I, Paunović V. Instrumenti kliničke procene u psihijatriji. Beograd: Institut za mentalno zdravlje 2003:130-134.

37. Stage K.B, Middelboe T, Pisinger C. Depression and chronic obstructive pulmonary disease (COPD). Impact od survival Acta Psychiat Scand 2005;11:320-323.

38. Norwood R.J. A review of etiologies of depression in COPD International Journal of COPD 2007:2(4) 485-491.

39. Glassman AH, Helzer JE, Covey LS, Cottler LB, Stetner F, Tipp JE, Johnson J.

40. Smoking, smoking cessation, and major depression. JAMA1990;264:1546-9.

41. Ng TP, Niti M, Tan WC. Depressive symptoms and chronic obstructive pulmonary disease. Arch Intern Med 2007;167:60-67.

\section{Ivana Jelić}

Faculty of Medical Sciences Kragujevac Lepenički bulevar 23/4, 34000 Kragujevac Mob: 063685116

E-mail: jelicivana82@yahoo.com 